\title{
Federal Policies for Increasing Socioeconomic Diversity at Selective Colleges and Universities
}

Elizabeth Davidson Pisacreta

Emily Schwartz

Catharine Bond Hill

Martin Kurzweil 


\section{ITHAKA S+R}

Ithaka $\mathrm{S}+\mathrm{R}$ provides research and strategic guidance to help the academic and cultural communities serve the public good and navigate economic, demographic, and technological change. Ithaka $\mathrm{S}+\mathrm{R}$ is part of ITHAKA, a not-for-profit organization that works to advance and preserve knowledge and to improve teaching and learning through the use of digital technologies. Artstor, JSTOR, and Portico are also part of ITHAKA.

Copyright 2021 ITHAKA. This work is licensed under a Creative Commons Attribution 4.0 International License. To view a copy of the license, please see https://creativecommons.org/licenses/by/4.0/.

ITHAKA is interested in disseminating this brief as widely as possible. Please contact us with any questions about using the report: research@ithaka.org. 


\section{Introduction}

Earning a bachelor's degree is increasingly important to an individual's longer-term economic prospects. Communities, at all levels, also benefit when their members earn postsecondary credentials, through improved economic, social, and health outcomes. Yet, despite an increase in college participation over the last two decades, severe inequities in bachelor's degree attainment remain; inequities that often leave lower-income and BIPOC (Black, Indigenous and people of color) students with debt and no or low-value credentials. ${ }^{1}$ With Democrats coalescing around a number of federal policy interventions, Congress and the Biden administration seem poised to take action to address these inequities and increase attainment.

The policies under consideration rightfully prioritize federal investment to make college more affordable for low- and middle-income students and to increase resources at broad-access institutions-community colleges and regional four-year publics, especially-that are serving lower-income and BIPOC students in large numbers. Some ideas on the table are: doubling the federal Pell grant ${ }^{2}$ and making other strategic changes to federal grant programs; making some or all public colleges free; subsidizing institutions that serve large shares of underrepresented students; and reducing or eliminating student loan debt. ${ }^{3}$ Investments in broad access institutions are even more important in the wake of a global pandemic that has led to severe unemployment and deep cuts to state budgets, magnifying historical cuts to higher education after the 2008 Great Recession. These investments are essential to increasing enrollment at these institutions and supporting students through graduation and beyond.

Yet investing in these institutions addresses only one dimension of the equity issue in higher education. Much like the American economy more broadly, higher education's resources are currently concentrated in a relatively small number of institutions and are spent on a disproportionately white and wealthy student body. For example, as of 2015-16, 23 public and private non-profit four-year institutions, serving just six percent of full-time equivalent postsecondary enrollments, held approximately 50 percent of all endowment assets, while the other 1,352 public and private non-profit four-year institutions shared the other half. 4 Furthermore, the average educational spending per student at the 133 most selective private four-year institutions is more than $\$ 75,000$, compared to under $\$ 33,000$ at all other four-year

\footnotetext{
${ }^{1}$ Margaret W. Callahan, Laura W. Perna, Marisha Addison, Chelsea Murray, Pooja R. Patel, and Nathan Jiang, "Indicators of Higher Education Equity in the United States: 2020 Historical Trend Report," The Pell Institute for the Study of Opportunity in Higher Education, Council for Opportunity in Education (COE), and Alliance for Higher Education and Democracy of the University of Pennsylvania (PennAHEAD), 2020, http://pellinstitute.org/downloads/publicationsIndicators of Higher Education Equity in the US 2020 Historical Trend Report.pdf.

${ }^{2}$ As explained in more detail later in this brief, the Pell grant is a federal need-based grant for higher education that is awarded predominantly to students with family income below $\$ 65,000$.

3 “Plan for Education Beyond High School: Joe Biden," Joe Biden for President: Official Campaign Website, 2020, https://joebiden.com/beyondhs/.

${ }^{4}$ Sandy Baum, Catharine Bond Hill, and Emily Schwartz, "College and University Endowments: In the Public Interest?" Ithaka S+R, May 22, 2018, https://doi.org/10.18665/sr.307377.
} 
institutions. ${ }^{5}$ At the same time, more than half of the students at selective institutions come from families in the top 20 percent of the national income distribution and fewer than 15 percent come from the bottom 40 percent of the income distribution. ${ }^{6}$ Black and Hispanic students are underrepresented at selective institutions by six and nine percentage points, respectively, and the underrepresentation of Native American students at selective institutions has actually increased since 2009.7 These inequities are not due to a lack of talented candidates: mounting research indicates that there are hundreds of thousands of high school graduates and community college students from underrepresented backgrounds poised to succeed at these institutions who do not have the opportunity to enroll in them. ${ }^{8}$

The concentration of financial and social capital in a few hundred selective and well-resourced institutions provides the students who attend them with educational and post-graduate opportunities that position them well for higher earnings, accelerated career trajectories, and leadership in the business, cultural, and political spheres. Four-year institutions that accept fewer than 25 percent of applicants graduate 90 percent of students in six years, and institutions with acceptance rates between 25 and 50 percent have a 70 percent graduation rate, compared to a 30 percent graduation rate at open admissions institutions. ${ }^{9}$ Attending a selective institution increases earnings, especially for Black, Hispanic, and lower-income students. ${ }^{10}$ And, the political and business leaders in our country frequently come from the most selective institutions - for example, Harvard, Stanford, and University of Pennsylvania have the most alumni in Fortune 500 CEO roles, and eight of the nine Supreme Court justices have law degrees from either Harvard or Yale. ${ }^{11}$ As long as those opportunities are largely reserved for the already well-to-do and well-connected, there will be a constraint on social and economic mobility. It is

\footnotetext{
${ }^{5}$ See Table 1 from Nick Hillman, "Why Rich Colleges Get Richer \& Poor Colleges Get Poorer: The Case for Equity-Based Funding in Higher Education," Third Way, November 20, 2020, https://www.thirdway.org/report/why-rich-colleges-get-richer-poor-collegesget-poorer-the-case-for-equity-based-funding-in-higher-education.

${ }^{6}$ Authors' analysis of Opportunity Insights Data, using all four-year public and private not-for-profits with six-year graduation rates consistently above 70 percent.

${ }^{7}$ Tomas Monarrez and Kelia Washington, "Racial and Ethnic Representation in Postsecondary Education," Urban Institute, June 2020, https://www.urban.org/sites/default/files/publication/102375/racial-and-ethnic-representation-in-postsecondaryeducation 1.pdf.

${ }^{8}$ Anthony P. Carnevale, Peter Schmidt, and Jeff Strohl, "The Merit Myth: How Our Colleges Favor the Rich and Divide America," The New Press, May 2020; Caroline Hoxby and Chris Avery, "The Missing "One-Offs": The Hidden Supply of High-Achieving, Low Income Students," NBER, December 2012, https://www.nber.org/papers/w18586; Tania LaViolet, Benjamin Fresquez, McKenzie Maxson, and Josh Wyner, "The Talent Blind Spot: The Case for Increasing Community College Transfer to High Graduation-Rate Institutions," The American Talent Initiative, June 2018, https://americantalentinitiative.org/wp-content/uploads/2018/07/AspenATI Vol.1 The-Case 07112018.pdf.

${ }^{9}$ National Center for Education Statistics, "Digest of Education Statistics," https://nces.ed.gov/programs/digest/d19/tables/dt19 326.10.asp. The selection of students with better academic preparation and more family resources as well as the greater resources spent on educating students at the selective institutions both contribute to these outcome disparities.

${ }^{10}$ Kevin Carey, "How Much Does Getting into an Elite College Actually Matter?" The New York Times, March 15, 2019, https://www.nytimes.com/2019/03/15/upshot/elite-colleges-actual-value.html.

${ }^{11}$ Statista, "Universities in the United States ranked by number of Fortune 500 CEO alumni in 2020," September 2020, https://www.statista.com/statistics/620257/us-universities-ranked-by-forbes-400-member-alumni/; Supreme Court of the United States, "Current Members," https://www.supremecourt.gov/about/biographies.aspx.
} 
imperative to reduce this "opportunity hoarding," in addition to increasing resources for the already-accessible educational pathways to the American Dream. ${ }^{12}$

The issue of limited socioeconomic diversity at selective institutions has received increased attention within higher education, by the media, and among policymakers over the last two decades. Leaders of selective institutions have organized to improve access in various ways, and there have been meaningful examples of both collective and individual progress. ${ }^{13}$ And yet, despite these efforts, overall progress during this period has been uneven-between 2012-13 and 2018-19, about half of the 102 most selective institutions have increased the share of Pell students enrolled, while the other half have seen declines.

An array of internal and external incentives and constraints have contributed to these results. Some of these, which we discuss in more detail below, include intense competition among these institutions for full-pay students and donors; other institutional priorities like research, athletics, personnel, and facilities, each of which has their own constituency and justification for attention; and dealing with a tumultuous economic climate, including the 2008 Great Recession and most recently the pandemic.

In several important ways, the federal policy environment has also made progress on socioeconomic diversity more difficult-which brings us to the focus of this brief.

In the sections below, we describe a package of four federal policy changes that would operate together to both prompt and facilitate selective colleges and universities to expand opportunity for lower-income students. ${ }^{14}$ The first two policies would set clear federal expectations around socioeconomic diversity and incentivize selective institutions to adhere to them: requiring a minimum share of lower-income undergraduate enrollment to participate in federal student aid and granting relief from a tax on high endowments in exchange for increasing the share of lower-income undergraduates. The two other policies will make it easier for institutions to follow through and increase the transparency of their efforts. One would expand an existing antitrust exemption to enable more institutions to reduce competitive practices that undermine socioeconomic diversity if they achieve demonstrable progress on increasing socioeconomic diversity. Finally, we discuss measures to improve the data on student socioeconomic status that

\footnotetext{
${ }^{12}$ Richard V Reeves, Dream Hoarders: How the American Upper Middle Class is Leaving Everyone Else in the Dust, Why That is a Problem, and What to Do About It (Washington, DC: Brookings Institution Press, 2017).

${ }^{13}$ For example, Ithaka $S+R$ is one of the partner organizations supporting the American Talent Initiative, a group of 132 highgraduation-rate institutions committed to increasing the number of low- and middle-income students they serve by 50,000 by the year 2025. In a series of reports, the American Talent Initiative has documented the collective progress of the group and highlighted numerous individual examples of selective institutions expanding opportunity, such as Franklin \& Marshall College, the University of California, Irvine, the University of Illinois, and Princeton University. See https://www.americantalentinitiative.org for more details on the initiative and its reports.

${ }^{14}$ We focus on policies that would result in greater enrollment diversity by students' income because economic mobility is a stated goal of much of federal and state support for higher education. While race and income are highly correlated in America, and greater socioeconomic diversity should contribute to racial diversity, we know that policies focused just on income will not be adequate to address the inequities in access to higher education by race. Affirmative action policies on the part of colleges and universities will be necessary for the foreseeable future, and progress on racial diversity should be tracked along with socioeconomic diversity.
} 
will permit policymakers, the public, and colleges themselves to better implement and monitor the full set of policies.

It is worth noting that none of these policies is wholly new-each has been proposed, at one time or another, most often as a standalone policy change. ${ }^{15}$ In our view, however, it is the combination of these motivating and facilitating policies, rather than each on its own, that is likely to achieve the desired outcome of increasing socioeconomic diversity at selective colleges and universities.

As a final note before detailing and analyzing the four policies, some commentators have expressed concern that pursuing federal policies focused on expanding access to selective colleges distracts from the higher priority need for investment in broad-access institutions. ${ }^{16} \mathrm{We}$ agree that it would be a mistake for federal policy to focus on selective-college access instead of broad-access-institution investment, yet we believe both goals can be pursued in a complementary way. Pursuing them is not zero-sum: both objectives are important and both can be pursued at the same time. ${ }^{17}$

To that end, the package of policies we discuss would require little new federal spending; instead, the proposals attach conditions to existing federal spending and revenue policies and alter regulatory requirements. They do not interfere or compete with proposals for large, general investments in affordability and support for public institutions. On the contrary, they reinforce policies such as increasing the Pell grant award and supporting tuition-free public college because they encourage selective colleges and universities to be productive participants in those programs by serving more lower-income students who benefit from them.

\footnotetext{
${ }^{15}$ For some examples, please see Appendix B.

${ }^{16}$ Nick Hillman, "Why Rich Colleges Get Richer \& Poor Colleges Get Poorer: The Case for Equity-Based Funding in Higher Education," Third Way, November 20, 2020, https://www.thirdway.org/report/why-rich-colleges-get-richer-poor-colleges-get-poorerthe-case-for-equity-based-funding-in-higher-education.

${ }^{17}$ Catharine Bond Hill and Martin Kurzweil, "Supporting Broad-Access Colleges and Increasing Opportunity at Selective Colleges Are Not Mutually Exclusive," The Hill, December 23, 2020, https://thehill.com/blogs/congress-blog/education/531394-supportingbroad-access-colleges-and-increasing-opportunity-at.
} 


\section{Incentivizing Selective Colleges to Enroll More Lower-Income Students}

\section{Proposal 1: Requiring a minimum Pell threshold to be eligible for Federal Student Aid}

Through the Federal Student Aid (FSA) program, the federal government currently provides approximately $\$ 120$ billion annually in federal grants and loans to eligible students to help them pay for college. ${ }^{18}$ These funds offset students' tuition and other charges and generate revenues at public and private colleges nationwide. The stated purpose of the Pell grant program, a cornerstone of FSA, is to "mak[e] available the benefits of higher education to qualified high school graduates of exceptional financial need, who for lack of financial means of their own or of their families would be unable to obtain such benefits without such aid."19 As mentioned above, four-year colleges and universities overall advance this purpose by serving student populations that are roughly 33 percent Pell-eligible. There are, however, a set of institutions, mostly selective, whose share of Pell-eligible students is far below this average. It would be reasonable for policymakers to ask that all institutions eligible to receive federal student aid advance the legislative goals of the program by serving at least a minimum share of students who are the intended beneficiaries of the program. ${ }^{20}$ Doing so would shift the standard for participation in FSA from having eligibility to receive payment of aid from some students, to bearing responsibility for providing at least a minimum of access for FSA-supported lower-income students.

In this section, we describe what such a policy requiring a minimum Pell share might look like. We identify which institutions might be affected because they currently fall below potential minimum thresholds and estimate the effects on their Pell enrollment and their finances of coming into compliance.

\section{Why Pell?}

There is a need to explain our (and others') use of the share of students receiving Pell as a measure of an institution's income diversity. Determining the actual income distribution of an institution's students is more difficult than one may imagine. Institutions often have incomplete information about the family income levels of prospective and enrolled students, and depending on the institution, may use different approaches to measure students' family income. Public

\footnotetext{
${ }^{18}$ U.S. Education Department, Federal Student Aid, https://studentaid.gov/.

${ }^{19}$ Higher Education Act of 1965, Title IV, Part A, Sec. 401(a).

${ }^{20}$ Colleges and universities are eligible for a number of federal financial aid programs through Title IV of the Higher Education Act. These "Title IV" funds provide grant, loan, and work-study funds to students, including the Federal Pell Grant, which is a need-based grant provided to low-income students. Currently, in order for a student to receive Title IV funds, the student must attend an institution eligible for the program. Institutional eligibility is granted if an institution is licensed and accredited to operate, and certified by the Department of Education to participate in the Title IV program. Our policy proposal applies to any institution that predominantly offers four-year degrees, enrolls at least 500 students, and is otherwise eligible to receive Title IV funds.
} 
reporting of income levels is similarly incomplete and incomparable across institutions. ${ }^{21}$ Students' receipt of a Pell grant is currently the only standard, widely-available measure of students' family income. ${ }^{22}$

Our proposals follow this practice and use the share of enrolled undergraduates receiving Pell grants to measure an institution's income diversity, with a few caveats. First, we understand that not all students who are eligible for Pell grants actually apply for and receive them. At community colleges especially, some portion of lower-income students may not apply for Pell grants because state or institutional grant aid is sufficiently generous to cover the cost of attendance. This can artificially depress the share of Pell students enrolled and subject institutions to financial penalties that are unwarranted. To minimize this possibility, our proposal focuses the incentives exclusively on four-year institutions with a minimum of 500 students enrolled and provides these institutions with a limited opportunity to appeal their eligibility under the policy. ${ }^{23}$

Second, we know that Pell eligibility is a blunt measure of students' family incomes. Most Pell recipients have family incomes below $\$ 30,000$, and nearly all have incomes below $\$ 65,000 .{ }^{24}$ But, efforts that focus on Pell enrollment can lead to enrollment losses amongst students near, but above, the Pell eligibility threshold. Over the longer-term, we can solve this problem by having better data on students' family incomes and using those data to develop more sophisticated measures of income diversity. To address this, we include a proposal later in this brief that calls for increased transparency and scope of federal student data collections, especially the family incomes of all students enrolled. Until federal data collection is improved, however, students' Pell status is the most nationally representative and comparable metric to use in this context.

Finally, one critique of using a Pell target specifically for public institutions is that they are also constrained to recruit some share of their students from within their state, and different states have different shares of Pell eligible students. A Pell target might force public institutions to enroll greater shares of Pell eligible students than higher income students relative to their state populations, but this would contribute to improving access and economic mobility. In addition, almost all public institutions recruit some students from out of state or internationally, so they could recruit Pell-eligible in-state students instead. Of course, this has significant financial implications, in part because out-of-state and international students often pay full tuition, that state policymakers might want to address.

\footnotetext{
${ }^{21}$ Benjamin Weintraut, Catharine B. Hill, Martin Kurzweil, and Elizabeth D. Pisacreta, "Comparing Public Institution-Level Data on Students' Family Income and Financial Aid," Ithaka S+R. November 16, 2020, https://doi.org/10.18665/sr.314398.

22 The fourth proposal in this paper seeks to address this by calling for improved collection and reporting of income data.

${ }^{23}$ While we will not further expand on the nature and details of the appeals process in this brief, we would caution against allowing an overly complex process or multiple exceptions that would lead to excessive administrative burden and delay in application of the policy. Furthermore, as part of the process, institutions should bear the burden of explaining why students who are eligible for Pell grants have not applied for and received those funds.

${ }^{24}$ Anthony P. Carnevale and Martin Van Der Werf, "The 20\% Solution: Selective Colleges Can Afford to Admit More Pell Grant Recipients," Georgetown University Center on Education and the Workforce and McCourt School of Public Policy, 2017, https://cew.georgetown.edu/cew-reports/pell20/.
} 


\section{What is the right Pell share threshold, and what are the financial implications of meeting it?}

Policymakers and advocates likely have varying opinions about the right minimum threshold to set. In our proposal, we set our minimum Pell threshold at 15 percent. This minimum meaningfully increases access for lower-income students at selective colleges and narrowly targets the incentive on those institutions with the lowest shares. For the purposes of discussion, however, we model the impacts of our policy using both a 15 percent threshold and a 20 percent threshold, a threshold that other researchers and policymakers have previously proposed. ${ }^{25}$ See the Appendix for a detailed description of our methodology and the institution-level data that generated these estimates.

As of Fall 2018, there are 88 four-year institutions with Pell enrollments below 15 percent and total enrollment above 500 (see Appendix for a link to a list of these institutions). Only nine of these 88 are public universities and the remainder are mostly private not-for-profit institutions, with a few health-focused and for-profit institutions in the mix. Seventy-seven have six-year graduation rates consistently above 70 percent, a threshold that only about 360 four-year institutions nationwide meet, and 74 are classified as most, highly, or very competitive using Barron's selectivity tiers.

If these 88 institutions increased their Pell enrollment to 15 percent, they would enroll an additional 11,468 Pell students, or on average, about 130 students per institution (with some smaller institutions only needing fewer than 10 students to reach 15 percent Pell). Currently, these 88 institutions serve 71,742 Pell students, so 11,468 additional would represent a 16 percent increase.

Of course, increasing Pell enrollment could require an increased investment in financial aid and losses in revenue on the margin, in addition to other likely costs associated with serving lowerincome students. To estimate potential revenue losses associated with our policy, we assume that newly enrolled Pell students would pay the same net price as current students from families with incomes between $\$ 0$ and $\$ 48,000$. We also account for Pell revenues equal to the average Pell grant at the institution (since net price is the estimate of the actual price a student will pay after grants and scholarships, we add the average Pell grant to this net price to account for Pell funds). We also assume that the institution enrolls a new Pell student in lieu of enrolling a nonPell student who pays either the institution's average net price or its sticker price. Under these assumptions, we estimate the range of institution-level revenue losses amongst this group of institutions is from $\$ 70,251$ to $\$ 26.7$ million if the tradeoff is the sticker price, and from no loss to $\$ 7$ million if the tradeoff is the average net price. ${ }^{26}$ The size of these losses depends on the

\footnotetext{
${ }^{25} \mathrm{Ibid}$.

${ }^{26}$ We estimate the revenue loss to the institution of increasing Pell share to be 15 percent by calculating the trade-off the institution faces on the margin: we compare the tuition revenue for a Pell student to the tuition revenue from either the average student or the full pay student. To estimate Pell student tuition revenues, we use the net price for students who receive Title IV aid and are from families with incomes between $\$ 0$ and $\$ 48,000$ combined with the average Pell grant at the institution. We estimate the trade-off by comparing this net price to the institution's average net price (lower bound) and the full cost of attendance (upper bound).
} 
institution's sticker price and their generosity in providing need-based financial aid, among other things. ${ }^{27}$

Obviously, these revenue losses are not trivial and would require a significant reallocation of resources from other areas to make up for them. Yet if Title IV eligibility were at stake, it would provide a powerful financial incentive to make the shifts necessary to meet the 15 percent threshold. For the 88 institutions subject to this policy, being ineligible to receive payments from Title IV aid would put at risk between $\$ 164,000$ and $\$ 325$ million in federal grants and loans per institution. ${ }^{28}$ For most of the 88 institutions, the federal revenue at risk is greater than the estimated revenue effects of enrolling the additional Pell students needed to meet the threshold. ${ }^{29}$

Of those 88 institutions with Pell shares below 15 percent and subject to our proposed policy, there are 14 institutions whose estimated revenue losses from meeting the 15 percent threshold are greater than their Title VI revenues. ${ }^{30}$ Many of these institutions are among the wealthiest in the country, enroll relatively small shares of Pell students, have the highest sticker prices, and offer the most generous financial aid to the lower-income students they do enroll. While these institutions would not necessarily feel substantial financial pressure to meet the 15 percent Pell share threshold, we expect the adoption of this policy would nevertheless substantially increase pressure on them to get above the threshold. This policy would clearly define, for the first time, a minimum acceptable Pell threshold, illuminating long-standing inequities in a new way. At the same time, participation in the federal financial aid system is a strong signal of commitment to public purpose. Combined with losing access to federal aid dollars, we believe the political and reputational costs of being on the wrong side of these bright lines would be sufficient to motivate those institutions to meet the minimum standard. In addition, if all colleges are encouraged to meet the 15 percent standard, doing so would not put any one institution at a competitive disadvantage.

It is important to note here that, if the maximum Pell grant were doubled, as President Biden and others have advocated, institutions would have even stronger incentives to maintain Title IV

\footnotetext{
${ }^{27}$ While the institution-level estimates we discuss in the text are most relevant in understanding how these costs would be borne, readers and policymakers may also be interested in understanding the aggregate effect of the policy. We estimate that if each of these 88 institutions increased their Pell enrollment to 15 percent, then, in aggregate, they would lose between $\$ 98$ and $\$ 403$ million in revenue, depending on the assumed replacement cost.

${ }^{28}$ The aggregate amount of federal grants and loans at risk for these 88 institutions is $\$ 1.6$ billion.

${ }^{29}$ Institutions could decide to forgo eligibility for federal student aid and try to offset some of the loss of Title IV revenue by recruiting more full-pay students, but as discussed later in the brief, there is a shrinking national pool of such students and there would likely be negative repercussions for pursuing that strategy, especially from a public relations standpoint.

${ }^{30}$ Harvard University, ${ }^{*}$ University of Chicago, Wake Forest University, Washington University in St Louis, Washington and Lee University, Lafayette College, Oberlin College, Bates College, Tufts University, Kenyon College, University of Notre Dame, Colgate University, Scripps College, Colorado College. This is the case if we assume that the institution is trading a Pell student for a full-pay student. If we assume that the institution is trading a Pell student for a student who pays average net price, there are no institutions with potential tuition revenue losses that are greater than their revenue from federal aid. *Note that Harvard University has publicly disputed that the Pell share reported via IPEDS is an appropriate depiction of socioeconomic diversity at the institution, as students from Harvard's Extension School are included in the calculation. For more context, please visit this link: https://economix.blogs.nytimes.com/2011/04/05/economic-diversity-at-harvard-cont/.
} 
eligibility and the financial aid costs of enrolling Pell-eligible students would decline. ${ }^{31}$ Analyzing the implications of doubling the maximum Pell grant is beyond the scope of this brief, but backof-the-envelope calculations suggest that doubling Pell could reduce institutions' estimated revenue loss of reaching the 15 percent threshold by 11 to 45 percent, depending on the institution.

For comparison, we also estimate the effect of setting the minimum Pell threshold at 20 percent. Doing so substantially increases the number of institutions below the threshold and their estimated revenue losses, and also substantially increases the number of Pell students who would gain access to these institutions. Using a 20 percent threshold, 203 four-year institutions would need to enroll an aggregate of 59,586 additional Pell students to remain eligible for Title IV aid. Because the overall average enrollment among this set of institutions is greater, the average number of Pell students per institution needed to meet the 20 percent threshold is 294, more than double the 130 students per institution needed under the 15 percent threshold. Currently, these 203 institutions serve 221,190 Pell students, so 59,586 additional would represent a 27 percent increase.

However, if the 203 institutions subject to this policy increased their Pell enrollment to 20 percent, we estimate that they would lose between $\$ 34,201$ to $\$ 59$ million per institution if the tradeoff is the sticker price, and between no loss and $\$ 19.2$ million per institution if the tradeoff is the average net price. ${ }^{2}$ The revenue losses are greater under a 20 percent threshold for two reasons: there are simply more institutions that are subject to the policy, and institutions, on average, have to add more Pell students to meet the target. Compared to the set of institutions subject to the 15 percent minimum threshold, these institutions are, on average, slightly more reliant on Title IV aid. Not surprisingly, because they are so much larger, the institutions with the most at stake are public institutions, and many more public institutions are subject to the policy under a 20 percent threshold than a 15 percent threshold.

There is nothing magical about either a 15 percent threshold or a 20 percent threshold, and policymakers may choose a different minimum than those we have modeled here. However, we would recommend a threshold closer to 15 percent, as it is likely to achieve meaningful additional access for lower income students while remaining targeted and avoiding the much larger financial disruption associated with the 20 percent threshold. In short, 15 percent functions as an effective minimum expectation for now. Regardless of the threshold, there would need to be some lead time between policy passage and the policy going into effect to ensure institutions have time to address the requirements-we would recommend four years to allow for institutions to respond to the policy through four admissions cycles, affecting most of their undergraduate enrollment. But, since the threshold operates with an existing program (Pell) and easily measurable target (percent of all students awarded Pell), implementation would be fairly

\footnotetext{
${ }^{31}$ It is worth noting that doubling Pell could have implications for both the dollar amount of the Pell grant and the Pell eligibility formula. Policymakers should monitor whether changes to the Pell threshold would be warranted if Pell eligibility were to change drastically.

32 The aggregate revenue loss would be between $\$ 400$ million for an average net price tradeoff and $\$ 1.9$ billion for a sticker price tradeoff.
} 
straightforward. Further, this threshold could be applied to the receipt of other, yet-to-bedetermined federal funds, such as funds for free public college.

\section{How does our policy relate to others?}

There are several, recent, prominent policy proposals that also aim to incentivize selective institutions to increase socioeconomic diversity through financial penalties associated with Pell share.33 Senator Chris Coons' ASPIRE Act, for example, proposes that colleges and universities whose share of first-time, full-time students receiving Pell grants are in the bottom five percent of the distribution of all four-year institutions pay a fee-per-student penalty based on the number of Pell students needed to rise above the threshold. 34 Policies outlined in a 2019 white paper from Senator Chris Murphy would impose a fine on institutions with significant Pell enrollment declines and restrict their access to federal campus-based aid programs (like work study and SEOG). 35

Although the ASPIRE act and the Murphy paper have the same objective as, and similar features to, our proposal, in our view, the penalties they propose are not strong enough to incentivize major shifts in institutions' enrollment strategies. Furthermore, because the eligibility thresholds they propose are continually shifting, the institutions affected by the policies are not sufficiently in the public view nor is the minimum acceptable Pell enrollment threshold up for public debate. Moreover, a relative target allows institutions to maintain objectively low Pell shares, as long as they are high relative to peers. Using rates of change to determine whether an institution is subject to the policy, as the Murphy paper suggests, could conceivably penalize those colleges and universities that, despite modest declines, are nevertheless maintaining a level of enrollment greater than others.

\section{Proposal 2: Offering an endowment tax credit for institutions with Pell shares above a threshold}

The policy we propose above establishes the expectation that institutions receiving payments of Title IV aid serve a minimum share of lower income students. To complement this minimum, we propose a second policy that encourages a subset of the wealthiest institutions to go beyond that minimum: those four-year colleges and universities that are currently subject to the endowment tax can reduce their tax burden if their Pell enrollment share exceeds a minimum threshold. Some of these institutions have made more progress than others on increasing socioeconomic diversity, and might immediately benefit from such a policy, rewarding their accomplishments to date.

\footnotetext{
${ }^{33}$ For example, see Michael Dannenberg and Mary Nguyen Barry, "Tough Love: Bottom-Line Quality Standards for Colleges," The Education Trust, June 17, 2014, https://edtrust.org/resource/tough-love-bottom-line-quality-standards-for-colleges/.

${ }^{34}$ Senator Coons' Office, "ASPIRE Act Legislative Section-by-Section," 2019, https://www.coons.senate.gov/imo/media/doc/ASPIRE\%20Act\%20Section-by-Section\%20.pdf.

${ }^{35}$ Senator Murphy's Office, "Are You Getting What You Pay For? A New Proposal for Accountability in Higher Education," 2019, https://www.murphy.senate.gov/imo/media/doc/HEA\%20White\%20Paper FINAL\%20(002).pdf.
} 
In late 2017, Congress passed a law to enact a 1.4 percent tax on the net investment income of institutions with endowments per student above \$500,000. Depending on the year and market performance, this legislation applies to anywhere from 25-40 institutions, nearly all of which are highly selective and well-resourced and many of which enroll small shares of lower-income students and BIPOC students. ${ }^{36}$ The tax rules and associated exemptions are complicated, and investment returns vary from year-to-year, so institutions' future tax liabilities are difficult to predict. Most institutions subject to the tax have not reported their past tax liabilities, but at the end of 2019, Harvard was expecting to pay about $\$ 50$ million. ${ }^{37}$

Our policy would introduce a reduction in the tax in a stepwise fashion, rewarding those institutions that have the highest Pell shares with greater reductions in the tax rate. Specifically, we propose using the same minimum Pell enrollment threshold as the prior policy (for now, 15 percent), and employing an endowment tax rate reduction of 0.2 percentage points for each percentage point above that threshold; thus, an institution would completely eliminate their endowment tax burden at a Pell share of 22 percent or above. We estimate that this tax credit would meaningfully reduce the tax burden for those institutions that increase Pell enrollment above the 15 percent threshold (Note: institutions have to enroll at least 16 percent Pell to realize the credit).

Using 2018 endowment and enrollment information, there are 28 institutions that are hypothetically subject to the endowment tax. $3^{8}$ Of those 28,15 institutions have Pell shares at or above 16 percent, so would immediately be eligible for a tax credit. Three of these 15 institutions have Pell shares at or above 22 percent-the threshold at which the tax rate phases completely out-and would therefore owe no endowment tax. We estimate that this tax credit would range from about $\$ 496,000$ to $\$ 7$ million, depending on the size of the institution's endowment return and where they fall at or above 16 percent Pell. For the institutions with Pell shares between 16 and 22 percent Pell, we estimate that a one percentage point increase in Pell enrollment would cost an institution between approximately $\$ 259,000$ (the lowest value assuming an average net price student trade-off) and \$5.05 million (the highest value assuming a full-pay student tradeoff). The size of the credit associated with these costs obviously depends on the size of the endowment, but the potential tax savings associated with a 0.02 percentage point reduction in the tax rate ranges from $\$ 187,000$ to $\$ 2.5$ million, depending on the institution (again, for those with Pell shares below 22 percent and therefore have not yet maximized their tax savings).

Of the 28, 13 institutions enroll less than 16 percent Pell students, so would need to increase their Pell enrollment share in order to receive any credit. For these institutions, the institutionlevel cost of increasing Pell enrollment share to 15 percent and then to 16 percent (to realize the tax credit) ranges from $\$ 151,000$ to $\$ 7.1$ million. For these institutions, the potential tax savings associated with a 0.02 percentage point reduction in the tax rate ranges from $\$ 29,000$ to $\$ 3.7$

\footnotetext{
${ }^{36}$ The number of institutions subject to the endowment tax varies from year-to-year due to changes in the market performance of institution's endowments.

${ }^{37}$ Rick Seltzer, "\$50 Million Tax Bill for Harvard," Inside Higher Ed, October 25, 2019, https://www.insidehighered.com/quicktakes/2019/10/25/50-million-tax-bill-harvard.

${ }^{38}$ We use IPEDS' 2018 beginning-of-year endowment market value and 2018 counts of FTE students to hypothesize eligibility. There is no definitive retrospective or prospective public list of institutions subject to the endowment tax.
} 
million. An increase to 16 percent Pell at these institutions would collectively add an additional 2,128 Pell students, a 30 percent increase from the current enrollment of 7,033 Pell students. While these institutions have a relatively weak incentive to get to 16 percent under proposal 2, most would have a strong incentive to get to 15 percent under proposal 1. At that point, the trade-offs for incremental gain are similar to those for institutions currently between 16 percent and 22 percent.

For some institutions, the size of the tax credit for even those incremental gains may not be large enough to justify the revenue losses incurred from increasing Pell. Our estimations above demonstrate the possible policy effects under a set of fixed assumptions, but policymakers could consider modifying the policy components to strengthen the incentive, apply it to more institutions, and/or promote larger increases in Pell:

- First, they could lower the threshold for endowment tax eligibility. Currently, an institution must have endowment value per FTE greater than $\$ 500,000$ to be subject to the tax. If the eligibility threshold were $\$ 250,000$ per FTE instead, we hypothesize that approximately 65 institutions would be subject to it.

- Second, they could raise the Pell enrollment share threshold that triggers the tax credit. We propose a 15 percent threshold in order to align the thresholds in our first and second proposals, but policymakers could increase the Pell share threshold to encourage the wealthiest institutions to increase Pell enrollment beyond the established minimum.

- Finally, they could reduce or enlarge the size of the tax credit itself. Currently, we propose a 0.02 percentage point reduction in the tax rate for every percentage point above the threshold. Instead, policymakers could halve or completely eliminate the tax rate at a specified threshold, or phase in a 0.01 percentage point reduction, thereby raising the threshold at which the tax is completely eliminated.

Many of the institutions subject to the endowment tax lobbied extensively against the passage of the tax in 2017, and would prefer that it be repealed completely. Yet all of these institutions have relied for decades on federal and state income tax exemptions to maximize the returns on their endowments. Some have done so while broadening access for lower-income students, while others have not broadened access. With the tax already in place, it would be reasonable for policymakers to reward those who have served this public policy goal already and provide a further reduction or elimination of the tax to those who advance it further. 39

\footnotetext{
${ }^{39}$ Some commentators on drafts of this brief have argued that attaching conditions to a reduction in the endowment tax sets a bad precedent that future legislators could take advantage of to impose other conditions that may be regressive rather than progressive. We do not find this argument persuasive. The endowment tax was introduced in the first place for what seemed to be punitive reasons, breaking a precedent. We see no reason to think that conditioning the existing tax to achieve an important public policy goal would somehow further embolden the already bold, or that refraining from doing so would somehow restrain future legislators from breaking that precedent, too.
} 


\section{Regulatory Changes to Support the Incentive Policies}

\section{Proposal 3: Expand the existing "need-blind" antitrust exemption to permit a broader set of institutions to coordinate on financial aid and admissions}

Under current antitrust law, agreements among colleges and universities regarding admissions and financial aid are subject to the Sherman Antitrust Act and associated regulations. $4^{\circ}$ While there is a limited, statutory exemption (which we will discuss in a moment), and while colleges and universities could assert that pro-competitive agreements subject to the Act are nevertheless permissible under the "rule of reason," 41 risk-averse higher education leaders and sometimes aggressive inquiries by the Department of Justice under both the Obama and Trump Administrations have largely kept colleges and universities far away from testing the limits of permissible coordination. 42

In the absence of constraints on competition for students, colleges and universities have spent huge sums of money-and many have built their business models-on recruiting and attracting the most "desirable" students; generally, those who are the wealthiest. These competitive practices include: focusing marketing, school visits, and other promotional and recruiting tactics on wealthy students, their families, and schools; 43 admitting students who apply early decision, who are legacies, who are flagged by athletic coaches, whose families have committed to a major gift, or who are simply able to pay full tuition at a higher rate than others; 44 discounting tuition

\footnotetext{
40 See, e.g., United States v. Brown Univ., 5 F.3d 658 (3d Cir. 1993). For an excellent summary of the antitrust context of college and university admissions and financial aid, see Deborah Jones Merritt and Andrew Lloyd Merritt, "Agreements to Improve Student Aid: An Antitrust Perspective," Journal of Legal Education 67, no. 17 (2017).

${ }^{41} \mathrm{~A}$ rule of reason analysis triggers a three-step inquiry. As articulated by the Third Circuit in the Brown case, first, the plaintiff must show that the "agreement produced adverse, anticompetitive effects within the relevant product and geographic markets." Next, the defendant may "show that the challenged conduct promotes a sufficiently pro-competitive objective." If the defendant carries that burden, then "the plaintiff must demonstrate that the restraint is not reasonably necessary to achieve the stated objective." United States v. Brown Univ., 5 F.3d 658, 668-69 (3d Cir. 1993).

42 See National Association of Independent Colleges and Universities, "Issues \& Advocacy: Anti-Trust," https://www.naicu.edu/policy-advocacy/issue-brief-index/student-aid/anti-trust; Scott Jaschik, "NACAC Agrees to Change Its Code of Ethics," Inside Higher Ed, September 30, 2019, https://www.insidehighered.com/admissions/article/2019/09/30/nacac-agreeschange-its-code-ethics; Eric Hoover, "U.S. Opens Antitrust Investigation Into Colleges' Talk of Student-Aid Reform," The Chronicle of Higher Education, June 17, 2013, https://www.chronicle.com/article/u-s-opens-antitrust-investigation-into-colleges-talk-of-studentaid-reform. A 2003 bill that proposed an antitrust exemption for admissions collaboration had 10 cosponsors but was not passed. See S. 1793, College Quality, Affordability, and Diversity Improvement Act of 2003, https://www.congress.gov/bill/108thcongress/senate-bill/1793.

${ }^{43}$ Ozan Jaquette and Crystal Han, "Follow the Money: Recruiting and the Enrollment Priorities of Public Research Universities," Third Way, March 2, 2020, https://www.thirdway.org/report/follow-the-money-recruiting-and-the-enrollment-priorities-of-publicresearch-universities; Caroline Hoxby and Christopher Avery, "The Missing 'One-Offs': The Hidden Supply of High-Achieving, LowIncome Students," Brookings Paper on Economic Activity, Spring 2013, https://www.brookings.edu/wpcontent/uploads/2016/07/2013a hoxby.pdf.

${ }^{44}$ For example, see William G. Bowen, Martin A. Kurzweil, and Eugene M. Tobin, Equity and Excellence in American Higher Education (Charlottesville: University of Virginia Press, 2006); Melissa Korn and Jennifer Levitz, Unacceptable: Privilege, Deceit \& the Making of the College Admissions Scandal (New York: Penguin, 2020);
} 
for or awarding scholarships to students without demonstrated financial need;45 and spending money on upgraded campus amenities (such as housing, food, and recreational facilities). ${ }^{6}$ These practices are reinforced by rankings such as US News \& World Report, which reward some of them directly-such as higher spending (other than on need-based aid) per studentand others indirectly-like rewarding higher SAT and ACT scores that wealthier high school students are far more likely to attain. 47 They have also given rise to a billion-dollar industry of consultants devoted to "enrollment management," whose admissions and financial aid algorithms promise ever-greater precision in "yielding" those desirable students. ${ }^{48}$

Investing in these practices to entice higher income students to enroll has contributed to the rapid increase in the full price of attendance at selective institutions over the past thirty years. 49 This price increase, in turn, has made it more costly for selective colleges and universities to enroll low- and middle-income students who can afford to pay far less than full price, and made them even more dependent on enrolling students who can pay close to full price. As the competition for those students grows fiercer, colleges are willing to spend more on them and charge them less to enroll, in a vicious cycle that not only closes off opportunity for low- and middle-income students, but leaves all but the best endowed institutions in a perilous financial situation (made worse by growing income inequality and the declining numbers of wealthier, white high school graduates in each new cohort). $5^{5}$

Perversely, in the name of market competition, this arms race to win a subset of potential students has made selective colleges increasingly inaccessible to the vast majority of qualified potential students. It has sapped resources that might pay for financial aid based on qualified students' need, led admissions offices to choose less-qualified but wealthier students over morequalified applicants, and limited outreach to lower-income students, families, and high schools who therefore may not even realize attending a selective college is an option for them. And yet, even exploratory efforts among colleges to reign in these practices, like "merit aid" to wealthy

\footnotetext{
${ }^{45}$ National Association of College and University Business Officers, "The 2019 NACUBO Tuition Discounting Study," 2020, https://www.nasfaa.org/uploads/documents/NACUBO Tuition Discounting 2019.pdf; Stephen Burd, "Crisis Point: How Enrollment Management and the Merit-Aid Arms Race Are Derailing Public Higher Education," New America, February 13, 2020, https://www.newamerica.org/education-policy/reports/crisis-point-how-enrollment-management-and-merit-aid-arms-race-aredestroying-public-higher-education/.

${ }^{46}$ Catharine Bond Hill and Malcolm Gladwell, "Episode 5: Food Fight," Revisionist History, 2016. http://revisionisthistory.com/episodes/05-food-fight.

${ }^{47}$ Robert Morse and Eric Brooks, "How U.S. News Calculated the 2021 Best Colleges Rankings," U.S. News and World Report, September 13, 2020, https://www.usnews.com/education/best-colleges/articles/how-us-news-calculated-the-rankings.

${ }^{48}$ See Maggie McGrath, "The Invisible Force Behind College Admissions," Forbes, July 30, 2014, https://www.forbes.com/sites/maggiemcgrath/2014/07/30/the-invisible-force-behind-college-admissions/?sh=2ce6eaa470a5; Matthew Quirk, "The Best Class Money Can Buy," The Atlantic, November 2005, https://www.theatlantic.com/magazine/archive/2005/11/the-best-class-money-can-buy/304307/.

${ }^{49}$ Grey Gordon and Aaron Hedlund, "Accounting for the Rise in College Tuition," National Bureau of Economic Research 77, December 2018, http://www.nber.org/chapters/c13711.

${ }^{50}$ Nathan Grawe, Demographics and the Demand for Higher Education (Baltimore: Johns Hopkins University Press, 2018).
} 
students or poaching students who have already committed to another college, have been met with antitrust warnings and investigations from the Department of Justice. ${ }^{51}$

In order to serve the public interest and follow through on the incentives to enroll more lowerincome students described above, selective colleges will need to unwind some of these competitive practices that are against the public interest. In order to do that, they will need to be able to coordinate under a safe harbor from antitrust liability, because unilaterally unwinding these practices poses too great a risk. As mentioned above, there is a current, limited exemption to the Sherman Act for coordination around admissions and financial aid. The current statutory exemption permits "institutions of higher education ... to agree ... to award ... financial aid only on the basis of demonstrated financial need" as long as the institutions admit all students "on a need-blind basis." Those institutions may "use common principles of analysis for determining the need of such students for financial aid." 52

Currently, there are 21 institutions that meet under the auspices of the exemption, calling themselves the 568 Group after the section number of the exemption in its authorizing legislation.53 These schools are among the wealthiest and most selective in the country. They have all committed to need-blind admissions and using only need-based aid per the statute. Collectively, just 16.8 percent of their students receive Pell grants; five of them would not meet the 15 percent threshold of our first proposal.

The exemption is too narrowly focused to be effective. There are very few institutions, given the current competitive pressure to enroll higher income students, who can afford to pay no attention to applicants' ability to pay in the admissions process and not all of those eligible have chosen to participate in the 568 Group. Furthermore, it focuses on only two practices in admissions and financial aid, leaving a whole range of other practices in outreach, admissions (e.g., legacy and athletic admissions), and campus amenities that can be used to favor wealthier applicants and are not subject to coordination. Moreover, it addresses only certain practices and not the outcome of real interest: diversifying enrollment. And, finally, on its own, it provides no incentive to participate, other than perhaps a reputational boost for joining in the coordination or shame for not joining. Indeed, seven members have left the 568 group since it was founded in 1998, and close peers of current members are not in the group (e.g., only four of the seven Ivy League institutions are members, though all adhere to need-blind admissions and award only need-based aid).

We propose to amend and expand the exemption to permit colleges and universities that opt in to reach agreement on common rules and practices for outreach, admissions, and financial aid

\footnotetext{
${ }^{51}$ See National Association of Independent Colleges and Universities, "Issues \& Advocacy: Anti-Trust," https://www.naicu.edu/policy-advocacy/issue-brief-index/student-aid/anti-trust; Scott Jaschik, "NACAC Agrees to Change Its Code of Ethics," Inside Higher Ed, September 30, 2019, https://www.insidehighered.com/admissions/article/2019/09/30/nacac-agreeschange-its-code-ethics; Eric Hoover, "U.S. Opens Antitrust Investigation Into Colleges' Talk of Student-Aid Reform," The Chronicle of Higher Education, June 17, 2013, https://www.chronicle.com/article/u-s-opens-antitrust-investigation-into-colleges-talk-of-studentaid-reform.

5215 U.S.C. $§ 1$ note (2017) (codifying Pub. L. No. 103-382, title V, § 568(a), 108 Stat. 4060, as amended).

${ }^{53} 568$ Presidents Group, "What is the 568 Presidents Group?" https://www.568group.org/home/.
} 
that increase the enrollment of and improve graduation and affordability for lower-income students at their institutions. Allowable activities may include using common principles for determining students' financial need, focusing financial aid on needy students, limiting aggressive recruiting practices, using a common aid application, and exchanging family financial data with regard to jointly admitted students. Participating colleges would need to be subject to external monitoring-and would likely benefit from external facilitation-to ensure the negotiated activities stay within bounds. They would also be responsible for demonstrating, after a period of time, that agreed-upon rules and activities were associated with improvements in enrollment, affordability, and success for lower-income students at their institutions.

Proposals 1 and 2 would certainly encourage institutions affected by them to participate in the coordination. But there is a broader set of private, mostly small institutions that are above the minimum threshold for Pell enrollment in Proposal 1 and have endowments far too small to be subject to Proposal 2, yet would seize the opportunity to lower the heat on the arms race for wealthier students because that arms race risks bankrupting them. And there are selective public universities whose practice of competing for wealthy out-of-state students to balance their budgets is straining their finances and putting them crosswise with their legislatures, who would welcome the chance to ratchet down those wasteful expenditures. While we believe an exemption like the one we describe would enable colleges and universities to follow through on Proposals 1 and 2, it also may be the catalyst that changes the current vicious cycle of competition into a virtuous cycle of cooperation that greatly benefits low- and middle-income aspiring college-goers.

\section{Proposal 4: Improve federal data collection from U.S. colleges and universities and increase data transparency}

Improving data collection and transparency will help policymakers, the public, and colleges themselves better monitor adherence to and effectiveness of the policies described above. Currently, the federal government is prohibited from collecting and reporting student-level data that could generate comprehensive statistics for all enrolled students on the income distribution, net price by income, or graduation outcomes by income. 54 Colleges themselves do not collect income data for all of their students, with little leverage to do so for students who do not apply for financial aid.

One recent, bipartisan proposal to remedy these challenges is the College Transparency Act (CTA). The CTA would overturn the ban on student-level data collection implemented during the 2008 reauthorization of the Higher Education Act, allowing for the collection of more complete data related to access, success, cost, and postgraduate outcomes. The proposal also calls for a transparent and easy-to-use data system that would allow aggregate data to be widely accessible. Data-sharing agreements across federal agencies (like through the US Department of

\footnotetext{
${ }^{54}$ Database of student information prohibited, 20 U.S.C. 1015c (2008), retrieved from https://www.law.cornell.edu/uscode/text/20/1015c.
} 
Education and Internal Revenue Service) would be encouraged, expanding the types of data that could be included and reported. 55

The CTA is a good step towards transparency and would help policymakers implement the previously proposed policies. Two amendments to the policy, however, could help us more fully understand income diversity at selective institutions: requiring the collection and reporting of students' income information, not just their Pell status; and ensuring that all students are included in the collection and reporting.

For the first amendment, while the CTA would require the collection and reporting of students' Pell status, it does not immediately require the collection or reporting of students' family incomes-though it does permit the Commissioner of the National Center for Educational Statistics (NCES) to go through a process to include additional data elements, such as students' "economic status." ${ }^{6}$ There is a need for the second amendment because, currently, most institutions only collect income data for students who complete the Free Application for Federal Student Aid (FAFSA) or complete other forms to apply for institutional financial aid.

Institutions typically have no income data for students who do not apply for any financial aidtypically wealthy students who can afford to pay out-of-pocket. These missing data obscure the true income distribution at an institution, only reporting on those at the bottom of the income distribution and yielding no information on the incomes of those at the top. Thus, even if institutions were required to report students' income to the NCES, they would still be limited to reporting the incomplete income data they possess.

One way to expand the number of students included in the data collection and reporting required by CTA is to introduce a requirement that all applicants complete the FAFSA, a tactic often referred to as "universal FAFSA." Recently, there is increased momentum for universal FAFSA completion, especially as completion rates among lower-income high schoolers are down due to the COVID-19 pandemic and financial crisis. 57 For instance, many states have added FAFSA completion to their high school graduation requirements. ${ }^{8}$ Policymakers could require that four-year colleges eligible for Federal Student Aid be required to collect the FAFSA from every applicant, with a few exceptions. All students in higher education, including wealthy students, benefit from significant public subsidies, which justifies requiring some universal disclosure of income and assets. And, now that Congress passed legislation to simplify the

\footnotetext{
${ }^{55}$ Senator Bill Cassidy, "S. 800 College Transparency Act," U.S. Senate, March 2019, https://www.congress.gov/bill/116thcongress/senate-bill/800/text; Institute for Higher Education Policy, "College Transparency Act: S. 800 / H.R. 1766," http://www.ihep.org/sites/default/files/uploads/postsecdata/docs/resources/college transparency act - one pager 004.pdf.

${ }^{56}$ S. 800 College Transparency, sec. 2, https://www.congress.gov/bill/116th-congress/senatebill/800/text\#id5d117fd6fc22438ba53e3c2aab3d9f79.

${ }^{57}$ Form Your Future, "FAFSA Tracker," 2021, https://formyourfuture.org/fafsa-tracker/.

${ }^{58}$ Megan Leonhardt, "These 3 States Will Require You to File a FAFSA to Graduate from High School," CNBC, September 30, 2019, https://www.cnbc.com/2019/09/30/3-states-will-require-you-to-file-a-fafsa-to-graduate-from-high-school.html.
} 
FAFSA, the barriers to completion are lower, for underrepresented and wealthy students, alike. 59

Colleges could include these income data in their regular reporting to the NCES' Integrated Postsecondary Education Data System (IPEDS) or in future reports designated under the CTA. Some limited exemptions might be needed to avoid discouraging lower-income students from applying to colleges where they will not need federal aid and for undocumented students, until DACA issues get resolved. It may also be possible to further reduce the burden of completing FAFSA by, for example, offering applicants the opportunity to release relevant information from their tax records to designated recipients in lieu of completing the form, or limiting the information required to the bare minimum for students with straightforward financial situations.

While our proposals here are focused on income, we hope that over time increased data transparency will allow for a comprehensive focus on students' wealth as well. We know that, controlling for income, racial gaps in wealth persist, and that solely focusing on income will not adequately address concerns about racial diversity. ${ }^{60}$

With better data on the income distribution of students, it would be possible to use a more nuanced set of measures than Pell share in the proposals described above. Better data on the income distribution of students will also help protect against institutions increasing the share of Pell recipients at the expense of students with incomes just above the Pell cut-off. This will be even more important if Pell eligibility were to expand, to ensure that institutions are not disproportionately focusing on students on the higher-income end of Pell eligibility. In addition, more comprehensive data will allow policymakers to monitor other important student outcomes, like retention and graduation rates for low-income students, to ensure that increases in Pell enrollment are not coming at the expense of student support and success. Legislation enacting these proposals should account for future improvements in data availability and allow for flexibility in the future implementation of the policies, accordingly.

\section{Conclusion}

Lower-income and BIPOC students attend broad access institutions in large numbers, making those institutions the top priority for federal policy support, especially in the fallout of the global pandemic and economic crisis that have disproportionately impacted those same groups.

Numerous policy proposals, including many from President Biden during his campaign, rightly target these students and institutions, looking to make college more affordable through doubling the Pell grant, making some or all public colleges free, subsidizing institutions that serve large shares of underrepresented students, and reducing or eliminating student loan debt.

\footnotetext{
${ }^{59}$ Cory Turner and Elissa Nadworny, "Congress Poised to Simplify FAFSA, And Help People In Prison Go To College," National Public Radio, December 20, 2020, https://www.npr.org/2020/12/20/948659930/congress-poised-to-simplify-fafsa-and-help-peoplein-prison-go-to-college.

${ }^{60}$ Kriston McIntosh, Emily Moss, Ryan Nunn, and Jay Shambaugh, "Examining the Black-White Wealth Gap," Brookings Institution, February 27, 2020, https://www.brookings.edu/blog/up-front/2020/02/27/examining-the-black-white-wealth-gap/.
} 
While a focus on broad access institutions is important, ignoring the selective, well-resourced institutions would be a missed opportunity. Lower-income and BIPOC students do not attend these institutions in large numbers despite being well-qualified and well-positioned to benefit from attending, and current federal policy does little to change that fact.

In this brief, we identify a package of policy changes that could operate alongside the broader approach to educational equity, and would both prompt and enable selective institutions to expand access to lower-income students. Setting a clear expectation that institutions participating in the Federal Student Aid program enroll at least 15 percent Pell-eligible students and offering an incremental endowment tax credit for institutions who serve higher shares than that minimum will together raise the priority level for increasing or maintaining broader access for students from the bottom half of the income distribution. A limited antitrust exemption and increased data collection and reporting would relax constraints and increase transparency, making it easier for institutions to follow-through on this public policy priority and for everyone to monitor the outcome.

By simultaneously supporting students and broad access institutions and incentivizing the wellresourced institutions to do more, the federal government can tackle problems of access and affordability from all sides. 


\section{Appendix A: Methodology}

A full list of institutions subject to proposal 1, along with some related data, is available to download at this link: https://sr.ithaka.org/appendix-federal-policies-for-increasing-

socioeconomic-diversity-institutions-subject-to-proposal-1/.

\section{Methodology}

Our estimations include all four-year private not-for-profit, public, and private for-profit institutions that are eligible for Title IV funding and enroll at least 500 undergraduate students. Depending on the policy threshold (15 percent or 20 percent), there are between five and nine institutions that we identify as subject to this policy that are missing the finance data necessary to make estimations of possible revenue losses and federal aid revenue at stake. As such, we include these institutions in the count of institutions subject to the policy, but they are not included in the estimations of revenue lost or federal aid at stake. We fully exclude the United States Merchant Marine Academy and the University of Oklahoma Health Sciences Center due to the nature of their programs and data reporting on Pell enrollment.

To estimate the trade-off between meeting the Pell threshold and losing Title IV funding, we estimate the following:

1. Estimated revenue loss of meeting threshold: These losses are calculated as a range, depending on the hypothetical trade-off the institution faces. The lower bound of the range assumes that the institution enrolls a Pell student instead of a student who pays the institution's average net price. The upper bound of the range assumes the institution enrolls a Pell student instead of a student who pays the full sticker price (or cost of attendance). To approximate Pell student tuition revenues, we use the average net price for students who receive Title IV aid and are from families with incomes between $\$ 0$ and $\$ 48,000$. We add the average Pell grant at the institution to this net price. We use the IPEDS student financial aid survey to identify cost of attendance, average Pell grant, and average net price information.

2. Total federal revenue at stake: We use the IPEDS finance survey to identify the institution's total federal revenue from Pell grants and federal student loans; we exclude revenues from federal work study and Supplemental Educational Opportunity Grant (SEOG) grants.

3. Difference in revenue loss and federal revenue: We take the difference between \#1 and \#2 to understand the strength of the incentive an institution faces. If this difference is positive, then we estimate that institutions-individually and in the aggregate-have a strong incentive to meet the Pell enrollment threshold: their potential losses in federal aid and loans outweigh their potential losses in enrolling enough Pell students to meet the minimum threshold. The magnitude of this incentive is also presented in a range because \#1 is a range. In this case, the lower bound assumes that revenue losses from enrolling a new Pell student are relatively higher (i.e., the Pell student replaces a student who pays full 
cost of attendance). The upper bound assumes that revenue losses are relatively lower (i.e., the Pell student replaces a student who pays average net price).

To estimate the tradeoff between a potential endowment tax credit and the cost to an institution to obtain that credit, we estimate the following:

1. Tax owed: We use the IPEDS finance survey to identify the institution's beginning-ofyear endowment value, and apply a five percent return rate to estimate the end-of-year endowment return. We then apply a 1.4 percent tax to the estimated endowment return to calculate the endowment tax burden. We use the institution's estimated endowment return rather than its net investment income to approximate its taxable investment income for two reasons:

a. the underlying data on endowment value is more readily available via public data sources, and

b. institutions that are subject to the endowment tax are able to claim a number of tax exemptions, which may result in their taxable income being closer to the endowment income than their net investment revenue.

2. Potential tax credit: We employ an endowment tax rate reduction of 0.2 percentage points for each percentage point above the Pell share threshold (in this case, 15 percent). The credit is the difference between the tax owed at the full tax rate (1.4 percent) and the tax owed at the reduced rate. Institutions with Pell shares below the threshold would not receive a reduction, and therefore, would receive no tax credit.

3. Cost of increasing Pell to the threshold needed to realize a tax credit: For institutions with Pell shares below 16 percent, we estimate an institution's lost revenue from increasing Pell enrollment to 16 percent (the threshold needed to realize the credit). For institutions with Pell shares of 16 percent or above, we estimate an institution's lost revenue from increasing Pell by one percentage point. For institutions with Pell shares of 22 percent or above, there is no potential cost associated with this policy, as the tax owed will be fully eliminated by the available credit. 


\section{Appendix B: Related Policy Proposals}

Similar policies to the ones included in this paper have been proposed in the past. Below are some examples:

Stephen Burd, Kevin Carey, Jason Delisle, Rachel Fishman, Alex Holt, Amy Laitinen, and Clare McCann, "Rebalancing Resources and Incentives in Federal Student Aid," New America Foundation, January 2013, https://static.newamerica.org/attachments/2325-rebalancingresources-and-incentives-in-federal-studentaid/NAF Rebalancing\%20Resources\%20FINAL.ob3617357444e40c2ao88e38239bboa24.pdf

Anthony P. Carnevale and Martin Van Der Werf, "The 20\% Solution: Selective Colleges Can Afford to Admit More Pell Grant Recipients," Georgetown University Center on Education and the Workforce and McCourt School of Public Policy, 2017, https://cew.georgetown.edu/cewreports/pell20/

The Century Foundation, “The Century Foundation's Top Policy Priorities for 2021," October 2020, https://production-tcf.imgix.net/app/uploads/2020/10/19172117/TCF2021 Final.pdf

Michael Dannenberg, “A College Access Wakeup Call for Dems,” NY Daily News, December 27, 2019, https://www.nydailynews.com/opinion/ny-oped-wakeup-call-on-college-access20191227-ljsztpnfyjddhh6toybk6gs64e-story.html

Michael Dannenberg, "Higher Education Recommendations for the First 100 Days in Office," Education Reform Now, December 2020, http://edreformnow.org/wpcontent/uploads/2020/12/100-Days-Higher-Ed-Policy-Brief-12.6-Final.pdf

Michael Dannenberg and Mary Nguyen Barry, “Tough Love: Bottom-Line Quality Standards for Colleges," The Education Trust, June 17, 2014, https://edtrust.org/resource/tough-love-bottomline-quality-standards-for-colleges/

Catharine Bond Hill, "FAFSA for All," Inside Higher Ed, February 24, 2020, https://www.insidehighered.com/views/2020/02/24/why-every-student-applying-collegeshould-be-required-fill-out-fafsa-opinion

Catharine Bond Hill, Martin Kurzweil, and Elizabeth Davidson Pisacreta, "Better Than We Thought: Comparing Publicly Available Data on College Students' Income Distribution," Ithaka S+R, Updated October 28, 2020, https://doi.org/10.18665/sr.311406

Martin Kurzweil and Josh Wyner, "Rich Kids Are Eating Up the Financial Aid Pot," The New York Times, June 16, 2020, https://www.nytimes.com/2020/06/16/opinion/coronaviruscollege-rich-kids.html

Deborah Jones Merritt and Andrew Lloyd Merritt, "Agreements to Improve Student Aid: An Antitrust Perspective,” Journal of Legal Education 67, no. 17, 2017 
Matthew Reed, The Institute for College Access and Success, "Time to Reexamine Institutional Cooperation on Financial Aid," June 2008. https://ticas.org/files/pub files/antitrust.pdf

The Reimagining Aid Design and Delivery (RADD) Consortium for Higher Education Grants and Work-Study Reform, "Beyond Pell: A Next-Generation Design for Federal Financial Aid," October 2014, https://edtrust.org/wp-content/uploads/2013/10/BeyondPell FINAL.pdf

S. 1793, College Quality, Affordability, and Diversity Improvement Act of 2003, https://www.congress.gov/bill/108th-congress/senate-bill/1793

Benjamin Weintraut, Catharine Bond Hill, Martin Kurzweil, and Elizabeth Davidson Pisacreta, "Comparing Public Institution-Level Data on Students' Family Income and Financial Aid," Ithaka S+R, November 16, 2020, https://doi.org/10.18665/sr.314398 